\title{
Exposome and Skin. Part 2. The Influential Role of the Exposome, Beyond UVR, in Actinic Keratosis, Bowen's Disease and Squamous Cell Carcinoma: A Proposal
}

\author{
Manuel Molina-García (1) · Josep Malvehy (1) · Corinne Granger (1) · \\ Aurora Garre (1) · Carles Trullàs (1) · Susana Puig (1)
}

Received: October 2, 2021 / Published online: February 3, 2022

(C) The Author(s) 2022

\begin{abstract}
Actinic keratosis (AK) is the main risk factor for the development of cutaneous invasive squamous cell carcinoma (SCC). It represents the first sign of severe chronic ultraviolet radiation exposure, which has a clear significant effect. Nevertheless, the skin is exposed to many other exposome factors which should be thoroughly considered. Our aim was to assess the impact of
\end{abstract}

M. Molina-García · J. Malvehy · S. Puig ( $\varangle)$ School of Medicine and Health Science, University of Barcelona (UB), 143 Casanova, 08036 Barcelona, Spain

e-mail: spuig@clinic.cat; susipuig@gmail.com

M. Molina-García · J. Malvehy · S. Puig Institut d'investigacions Biomèdiques August Pi i Sunyer (IDIBAPS), Barcelona, Spain

M. Molina-García $\cdot$ J. Malvehy $\cdot$ S. Puig Dermatology Department, Melanoma Unit, Hospital Clinic, Universitat de Barcelona, 170 Villarroel, 08036 Barcelona, Spain

M. Molina-García

e-mail:manmolina@clinic.cat;

manuel.molina@ub.edu

J. Malvehy · S. Puig

Centro de Investigación en Red de Enfermedades

Raras (CIBERER), Instituto de Salud Carlos III,

Barcelona, Spain

C. Granger · A. Garre · C. Trullàs

Innovation and Development, ISDIN, 33

Provençals, 08019 Barcelona, Spain exposome factors other than ultraviolet radiation (UVR) on the etiopathology of AK and Bowen's disease (BD) and progression of AK to SCC and to design tailored prevention strategies. We performed an exhaustive literature search in September 2021 through PubMed on the impact of exposome factors other than UVR on $\mathrm{AK}, \mathrm{BD}$ and SCC. We conducted several parallel searches combining terms of the following topics: AK, BD, SCC and microbiome, hormones, nutrition, alcohol, tobacco, viral infections, chemical contaminants and air pollution. Notably, skin microbiome studies have shown how Staphylococcus aureus infections are associated with AK and AK-to-SCC progression by the production of chronic inflammation. Nutritional studies have demonstrated how a caloric restriction in fat intake, oral nicotinamide and moderate consumption of wine significantly reduce the number of premalignant keratoses and SCC. Regarding lifestyle factors, both alcohol and smoking are associated with the development of SCC in a dosedependent manner. Relevant environmental factors are viral infections and chemical contaminants. Human papillomavirus infections induce deregulation of cellular proliferation and are associated with AK, BD and SCC. In addition to outdoor jobs, occupations such as industrial processing and farming also increase the risk of developing keratoses and SCC. The exposome of AK will undoubtedly help the understanding of its etiopathology and possible progression to 
SCC and will serve as a basis to design tailored prevention strategies.

Keywords: Actinic keratosis; Dermatology; Environmental factors; Exposome; Hormones; Microbiome; Nutrition; Pollution; Prevention strategies; Squamous cell carcinoma

\section{Key Summary Points}

The main environmental risk factor for Actinic keratosis (AK), Bowen's disease (BD) and squamous cell carcinoma (SCC) is ultraviolet radiation (UVR) and therefore photoprotection is always advisable.

Nevertheless, other host, environmental and lifestyle factors play a relevant role in the onset of $\mathrm{AK}$ and $\mathrm{BD}$ and progression to invasive SCC.

S. aureus infections, alcohol, tobacco, human papillomavirus, chemical contaminants and air pollution are clearly associated with AK and SCC development.

Bowen's disease is also associated with human papillomavirus infections and arsenic exposure.

Caloric restriction of fat intake, oral nicotinamide, moderate consumption of red wine and green leafy vegetables are beneficial to prevent AK and SCC.

\section{INTRODUCTION}

Actinic keratosis (AK) represents the first sign of severe solar skin damage. It is considered the most common precursor and the main risk factor for the development of invasive squamous cell carcinoma (SCC) [1]. There has been much controversy concerning its classification as a premalignant lesion or as an in situ carcinoma [2]. The European guidelines have defined it as an in situ carcinoma [3] and many dermatologists claim that it is the same lesion and that AK simply represents the initial lesion in a disease continuum that might progress, histologically and clinically, to invasive SCC $[4,5]$. In fact, the term AK has been recently reclassified as "keratinocytic intraepidermal neoplasia I-III (KIN I-III)" [6, 7] or "in situ SCC type AK I-III" [8]. Bowen's disease (BD) is sometimes referred to as SCC in situ, characterized by a proliferation of atypical intraepidermal keratinocytes filling the entire epidermis, including the granular layer $[9,10]$. AK progresses to invasive SCC in $10 \%$ of cases and several pathways have been proposed to explain this phenomenon such as the "classic" or the "differentiated pathway" [11, 12]. The risk of progression of $\mathrm{BD}$ to invasive SCC is generally considered to be about 3\%, of which approximately one-third may metastasize [13]. Undoubtedly, AK constitutes a major public health concern because of its high worldwide prevalence of between $11 \%$ and $25 \%$ and its potential for malignant transformation $[5,14]$. According to a systematic review, the rate of progression of single AK into SCC ranges between 0 and $0.53 \%$ per year with regression of single lesions between $15 \%$ and $63 \%$. Although the progression rate per lesion per year is small, in individuals with multiple AK lesions for more than 1 year, the risk for SCC development may be higher $[15,16]$. Cutaneous SCC, if left untreated, is a deadly threat owing to its ability to invade locally, spread via the lymphatic system, blood or by perineural invasion, metastasize to any organ in the body and eventually result in death $[17,18]$. Treatment of these lesions is highly recommended [3], although unfortunately most of the current treatments have local and systemic adverse effects [14]. Clearly, the best clinical approach is to identify the risk factors associated with the malignant onset and progression of these lesions to design better preventive strategies [18]. It is generally well acknowledged that the highest incidence rates are seen in elderly fair-skinned individuals, with light-coloured eyes and hair, skin that is prone to sunburn $[5,11,18-20]$ and especially those persons on immunosuppressive therapy [21-24]. A multicentre case-control study conducted in Europe showed how the risk for AK is seven times higher in persons with red hair, followed by those with white, blonde, dark 
blonde and light brown hair. They also observed a $40 \%$ reduced risk for AK in brown-eyed compared with blue-eyed persons, and a lower risk for darker phototypes. Sun exposure and sunburns during childhood significantly increased the risk for $\mathrm{AK}$ [25]. Another multicentre case-control study showed that chronic sun exposure was strongly associated with SCC [26]. In addition, many other studies have also pointed to ultraviolet radiation (UVR), which has a clear significant effect [27], as the main environmental trigger of AK [28], underestimating other relevant exposome factors. BD is also associated with UVR and immunosuppression, although other exposome factors such as viral infections and chemical contaminants are also of importance [10]. As the very first barrier between our body and the environment, the skin is exposed to many environmental, lifestyle and host factors from conception onwards which have been defined as the exposome $[29,30]$. Therefore, many exposome factors besides UVR could be playing an important role in the onset and progression of $\mathrm{AK}$ by the production of inflammation, oxidative stress, impaired apoptosis, mutagenesis, dysregulation of cell growth and proliferation, and tissue remodelling, which have all been described as the main mechanisms of AK formation [31]. Hence, the primary aim of this study was to assess the impact of exposome factors other than UVR and other than the well-known host factors (e.g. immunosuppression, gender, phototype) on the etiopathology of $\mathrm{AK}$ and $\mathrm{BD}$, and in the progression to invasive SCC. The secondary aim was to serve as a basis for physicians to define the relevant medical history of patients, and design tailored prevention strategies which complement sunscreens and exposure reduction to sunlight.

\section{METHODOLOGY}

We performed a broad literature search on articles published until September 2021 through PubMed on the impact of exposome factors other than UVR on AK, BD and invasive SCC. We conducted several parallel searches combining related terms of the following topics: actinic keratosis, squamous cell carcinoma, Bowen's disease and microbiome, hormones, nutrition, alcohol, tobacco, viral infections, chemical contaminants and air pollution. Relevant articles including in vitro, in vivo, ex vivo, clinical and epidemiological studies were selected for review. This article is based on previously conducted studies, and does not involve any new studies of human or animal subjects performed by any of the authors.

\section{INFLUENTIAL ROLE OF EXPOSOME FACTORS}

The AK, BD and SCC exposome consists of environmental, lifestyle and other host factors (Fig. 1) and their interactions affecting an individual and producing a specific biological response influencing the onset and progression into a malignant lesion (Table 1 ).

\section{Host Factors}

\section{Skin Microbiome}

Our skin is home to beneficial microorganisms with essential roles such as protecting us against

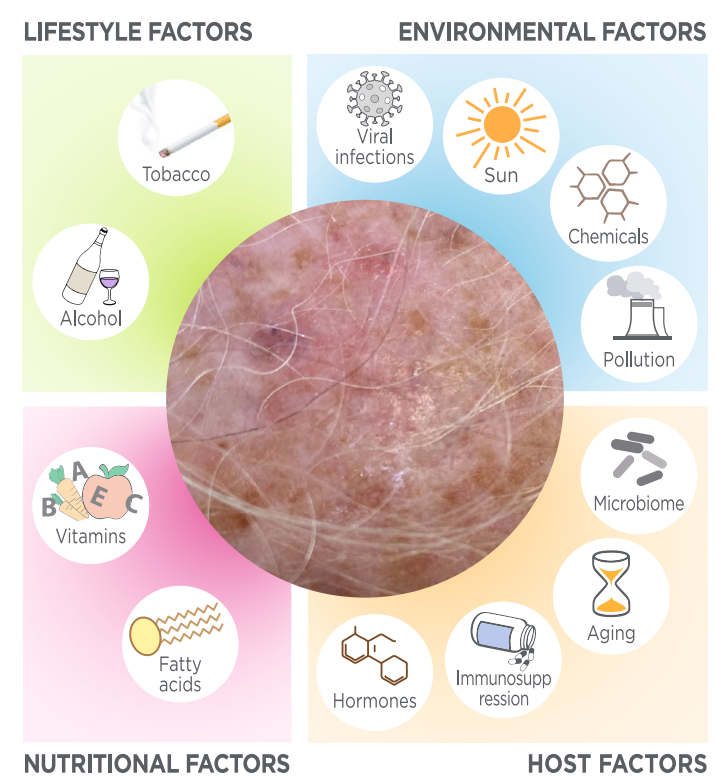

Fig. 1 Schematic map of the host, nutritional, lifestyle and environmental factors influencing $\mathrm{AK}, \mathrm{BD}$ and SCC 
Table 1 Summary of host, nutritional, lifestyle and environmental factors on AK, BD and invasive SCC

\begin{tabular}{|c|c|c|c|c|c|c|}
\hline \multirow[t]{2}{*}{ Exposome } & \multirow[t]{2}{*}{ Subclassification } & \multirow[t]{2}{*}{ Specific factors } & \multicolumn{3}{|c|}{$\begin{array}{l}\text { Risk/ } \\
\text { association }\end{array}$} & \multirow[t]{2}{*}{ References } \\
\hline & & & $\overline{\mathrm{AK}}$ & BD & $\overline{\mathrm{SCC}}$ & \\
\hline \multirow[t]{6}{*}{ Host } & \multirow[t]{2}{*}{ Microbiome } & S. aureus & $\uparrow$ & - & $\uparrow$ & {$[33-35]$} \\
\hline & & $\begin{array}{l}\text { Propionibacterium, } \\
\text { Malasezzia }\end{array}$ & $\downarrow$ & & $\downarrow$ & {$[34]$} \\
\hline & \multirow[t]{4}{*}{ Hormones } & Higher serum vitamin D & - & - & $\uparrow$ & {$[47,54-56]$} \\
\hline & & & - & - & $\downarrow$ & {$[53]$} \\
\hline & & $\operatorname{PPAR} \alpha, \operatorname{PPAR} \gamma$ & $\downarrow$ & - & $\downarrow$ & {$[58]$} \\
\hline & & $\operatorname{PPAR} \delta$ & $\uparrow$ & - & $\uparrow$ & {$[58]$} \\
\hline \multirow[t]{9}{*}{ Nutritional } & \multirow[t]{3}{*}{ Fatty acids } & Calorie restriction of fat & $\downarrow$ & - & $\downarrow$ & {$[65]$} \\
\hline & & High-fat diets & - & - & $\uparrow$ & {$[66-68]$} \\
\hline & & Oily fish (moderate intake) & $\downarrow$ & - & - & {$[74,86]$} \\
\hline & \multirow[t]{6}{*}{ Vitamins \& minerals } & Green leafy vegetables & - & - & $\downarrow$ & {$[66,67,74,86]$} \\
\hline & & Vitamin $\mathrm{B}_{3}$ & $\downarrow$ & - & $\downarrow$ & {$[82,83]$} \\
\hline & & $\beta$-Carotene & - & - & $\downarrow$ & {$[86]$} \\
\hline & & Vitamin C & - & - & $\downarrow$ & {$[86]$} \\
\hline & & Retinol & - & - & $\downarrow$ & {$[91]$} \\
\hline & & Selenium & - & - & $\uparrow$ & {$[92]$} \\
\hline \multirow[t]{3}{*}{ Lifestyle } & \multirow[t]{3}{*}{ Alcohol \& tobacco } & Wine & $\downarrow$ & - & - & {$[74]$} \\
\hline & & Alcohol & $\uparrow$ & - & $\uparrow$ & {$[103,104]$} \\
\hline & & Tobacco & - & - & $\uparrow$ & {$[107-112]$} \\
\hline \multirow[t]{8}{*}{ Environmental } & \multirow[t]{2}{*}{ Viral infections } & $\mathrm{HPV}$ & $\uparrow$ & $\uparrow$ & $\uparrow$ & {$[116,117,120,121,125-130]$} \\
\hline & & Merkel cell polyomavirus & - & $\uparrow$ & - & {$[132]$} \\
\hline & \multirow{3}{*}{$\begin{array}{l}\text { Chemical } \\
\text { contaminants }\end{array}$} & Arsenic & $\uparrow$ & $\uparrow$ & $\uparrow$ & {$[133,134,136-139]$} \\
\hline & & Coal tar, soot & $\uparrow$ & - & $\uparrow$ & {$[140]$} \\
\hline & & Paraquat & $\uparrow$ & - & $\uparrow$ & {$[144,145]$} \\
\hline & \multirow[t]{3}{*}{ Air pollution } & $\mathrm{PM}$ & - & - & $\uparrow$ & {$[153]$} \\
\hline & & $\mathrm{PAH}$ & - & - & $\uparrow$ & {$[157,158,160]$} \\
\hline & & Ozone depletion & - & - & $\uparrow$ & [169] \\
\hline
\end{tabular}

$A K$ actinic keratosis, $B D$ Bowen's disease, $H P V$ human papillomavirus, $P A H$ polycyclic aromatic hydrocarbons, $P M$ particulate matter, $P P A R$ peroxisome proliferator-activated receptors, $S C C$ squamous cell carcinoma 
invading pathogens and educating our immune system. Nevertheless, any imbalance between commensals and pathogens may lead to skin disease progression [32]. Several studies have compared the skin microbiome between AK, seborrhoeic keratosis (SK), SCC, basal cell carcinoma (BCC) and healthy skin [33-35]. Nevertheless, we did not find any study evaluating the role of the microbiota in BD. In a hospitalbased case-control study, Staphylococcus aureus DNA was strongly associated with SCC and there was also a trend for association with $\mathrm{AK}$ but no association was found for BCC or SK [33]. The study could not determine the possible causal or consequential relationship of the presence of S. aureus with AK and SCC although it is clear that acquisition of this bacteria was not due to mere protrusion of the lesions, since SK, a benign exophytic growth, did not show such association. A longitudinal, cross-sectional microbiome analysis conducted in immunocompetent men showed that Propionibacterium and Malasezzia organisms were relatively more abundant in non-lesional photodamaged skin than in AKs and SCCs. In contrast, Staphylococcus was most commonly associated with lesional skin, in particular, sequences most closely related to S. aureus [34]. Only some S. aureus-like operational taxonomic units (OTUs) were associated with SCC, which means that only particular strains of $S$. aureus are associated with SCC and could be used as possible biomarkers [34]. The distinction between the causal or the consequential role of $S$. aureus in the development of AK and AK-to-SCC progression is not clear, although both may be possible at the same time. The ulcerating growth characteristics and the reduced availability of sebum in both AK and SCC could partly explain the consequential $S$. aureus overabundance in these lesions. Propionibacterium, a common skin-colonizing bacterium, depends on sebum production to survive, and its decline may exacerbate lesion severity by disrupting the microbiome homeostasis and promoting S. aureus growth [34]. Conversely, S. aureus may be the cause of AK and AK-to-SCC progression by causing chronic inflammation, with the production of nitric oxide and cytokines which contribute to carcinogenesis [36-38]. Indeed, inflammation is a classical mechanism of carcinogenesis wherein oxidative stress and proinflammatory cytokines play a notorious role in oncogenesis, Helicobacter pylori and gastric adenocarcinoma being a clear example [39]. Interestingly, individuals with $\mathrm{AK}$ have shown a decline in RoxP concentration, an exogenous bacterial protein secreted by Propionibacterium acnes which modulates the redox status of the skin protecting the host from oxidative stress [40]. Furthermore, the staphylococcal alphatoxin has been shown to activate several cytokines and nuclear factor- $\kappa \mathrm{B}$ (NF- $\kappa \mathrm{B})$, supporting the hypothesis of the causative role of $S$. aureus in AK onset and progression to SCC [41]. Moreover, S. aureus overabundance has been significantly associated with human $\beta$-defensin 2 (h $\beta \mathrm{D}-2)$ expression, an endogenous antimicrobial peptide (AMP) with the ability to induce cell proliferation [35] and to stimulate keratinocyte migration and proliferation under the control of EGFR, STAT1, and STAT3 activation [42]. Overall, it would be of interest to develop biotherapeutics which stimulate the normal skin microbiota to the detriment of skin pathogen growth such as $S$. aureus. Curiously, Staphylococcus epidermidis, the antagonist of $S$. aureus, produces a molecule, 6-HAP (6- $\mathrm{N}$-hydroxyaminopurine), which reduces UV-induced skin tumours in mice by inhibiting DNA polymerase activity [43]. Furthermore, it has been demonstrated how certain commensals secrete UV-absorbing compounds such as mycosporine-like amino acids (MAAs), and enzymes, including superoxide dismutases (SOD), with antioxidant activity [44]. Accordingly, people should be encouraged to take care of their skin microbiota in order to complement sunscreens. Urbanization and excessive hygiene with soaps decrease skin microbiota diversity [45] and therefore it would be of interest to demonstrate if soap-free shower gels may help in the prevention of skin dysbiosis. UVR influences the cutaneous microbiota with both positive and negative consequences [44] and the beneficial or detrimental effect of sunscreens on the skin microbiota remains to be demonstrated. 


\section{Hormones}

Hormones (e.g. vitamin D, growth hormone or steroids) influence the development and function of human skin and cause a wide range of different biological responses through interaction with receptors [46]. Vitamin D is a clear example and is synthesized under the environmental influence of sun exposure, which is the main environmental risk factor for skin cancer [47]. Keratinocytes can convert vitamin $\mathrm{D}_{3}$ to its hormonal form, 1,25-dihydroxyvitamin $\mathrm{D}_{3}$ $\left[1,25(\mathrm{OH})_{2} \mathrm{D}_{3}\right]$ (calcitriol), which in turn stimulates their differentiation, raising the hope to prevent skin cancer [48]. In fact, 1 1 2,25 -dihydroxyvitamin $D_{3}$, the active form of vitamin $D_{3}$, has potential antiproliferative, prodifferentiative, and immunomodulatory activities and thus potential therapeutic applications in the treatment of AK and SCC [49]. Studies in animals have demonstrated that vitamin $\mathrm{D}_{3}$ hydroxyderivatives can attenuate chemically or UVB-induced epidermal carcinogenesis and inhibit growth of SCC and BCC [50]. Furthermore, vitamin D treatment decreases cell growth and metastasis in vitro [51, 52]. Nevertheless, the relationship in vivo between vitamin D and SCC is controversial and not well defined. The level of $25(\mathrm{OH}) \mathrm{D}$, the major circulating form of vitamin $\mathrm{D}$, is widely accepted as the best indicator of vitamin $\mathrm{D}$ status and vitamin $\mathrm{D}$ deficiency occurs if $25(\mathrm{OH}) \mathrm{D}$ levels are less than $20 \mathrm{ng} / \mathrm{mL}$ and insufficiency if less than $30 \mathrm{ng} / \mathrm{mL}$. In a nested case-control study, higher serum 25(OH)D levels were associated with a decreased risk of non-melanoma skin cancer (NMSC) in older Caucasian men [53]. Conversely, other studies, including a systematic review and meta-analysis, a prospective study, and a cohort study, have found positive associations between circulating $25(\mathrm{OH}) \mathrm{D}$ level and risk of SCC $[47,54,55]$. This positive association could be explained by the confounding effect of sun exposure, which is responsible for both vitamin D synthesis and skin carcinogenesis. Indeed, in a case-control study, vitamin D and SCC risk were directly associated in the unadjusted model but after correcting for the effect of undesired variables (including age, sex and sunlight exposure) there was no significant association [56]. Perhaps, the association between high vitamin D levels and SCC suggests that UV exposure may have a predominant adverse influence that exceeds any putative benefit from the higher levels of vitamin D. What is clear is that sun protection should always be advised, especially for patients with skin cancer, while ensuring adequate levels of vitamin D [57]. Hormone receptors are also important in both AK and SCC. The peroxisome proliferator-activated receptors (PPARs) are members of the nuclear receptor superfamily that regulate important cellular functions in skin, including cell proliferation and differentiation, as well as inflammatory responses. It has been reported that PPAR $\alpha$ immunoreactivity is reduced in human keratinocytes of SCC and AK, while PPAR $\delta$ appears to be upregulated. PPAR $\delta$ has been demonstrated to have an anti-apoptotic role and to maintain survival and differentiation of epithelial cells, whereas PPAR $\alpha$ and $\operatorname{PPAR} \gamma$ activators induce differentiation and inhibit proliferation and regulate apoptosis [58]. We did not find any study evaluating the potential role of hormones in the development of BD.

\section{Nutritional Factors}

\section{Quality and Quantity of Free Fatty Acid Consumption}

The first evidence that high-fat diets influence the development of ultraviolet radiation (UVR)induced skin cancer in experimental animals was reported in 1939 [59]. It has been shown that high-fat diets markedly shorten the time between UV exposure and tumour appearance and increase tumour multiplicity [60, 61]. Interestingly, experimental studies have shown how caloric restriction inhibits the formation of skin tumours in animals [62-64]. One dietaryintervention trial clearly demonstrated how a large decrease in calories consumed as fat reduces the incidence of $\mathrm{AK}$ in humans. In this study, subjects who were assigned to the intervention group with a low-fat diet $(20 \%$ of energy from fat) for 2 years developed $3 \pm 7$ (mean \pm SD) AKs, which was significantly fewer than the $10 \pm 13$ AKs observed in the control group (40\% of energy from fat) [65]. Indeed, 
several studies have shown an increased SCC tumour risk in susceptible persons, with increasing consumption of high-fat diets and consumption of unmodified dairy products, such as whole milk, cheese and yoghurt [66-68]. Several explanations have been proposed for the underlying mechanisms of high-fat diets and skin cancer, such as lipid peroxidation of unsaturated fatty acids, which plays a role in at least part of the photocarcinogenic response $[60,69]$, and photochemical conversion of skin cholesterol into carcinogenic substances [70]. Although polyunsaturated fatty acids (PUFA) are a clear target of free radical attack, a clear distinction has to be made between the effect of omega-3 and omega-6 fatty acids [71]. It has been shown that $\omega-6$ fatty acids significantly enhance carcinogenic expression and tumour multiplicity, especially in the post-initiation stage, while $\omega-3$ fatty acids inhibit UV-carcinogenesis even at high dietary levels [72]. Since there exists a connection between inflammation and cancer [38] it is logical that $\omega-3$ fatty acids have been shown to dramatically reduce the plasma and cutaneous pro-inflammatory and immunosuppressive prostaglandin $\mathrm{E}$ synthase type $2\left(\mathrm{PGE}_{2}\right)$ levels, while they increase the UVR-mediated erythema threshold in humans. Conversely, $\omega-6$ fatty acids increase $\mathrm{PGE}_{2}$, appear to act as tumour promoters, downregulate macrophage tumoricidal activities, inhibit interleukin-2 (IL-2) production, promote cellular hyperproliferation and tumour angiogenesis and suppress apoptosis [73]. Accordingly, in the dietary-intervention trial in which a large decrease in calories consumed as fat reduced the number of AK [65], there was also a reduction in levels of cholesterol and linoleic acid, an $\omega-6$ fatty acid [61]. Additionally, a longitudinal study conducted in Australia using a validated food-frequency questionnaire showed how a moderate intake of oily fish (an average of one serving every 5 days) decreases the rate of AK by $26 \%$ and $28 \%$ among participants with intermediate and the highest intakes of oily fish, respectively [74]. The explanation of AK improvement with oily fish such as salmon, tuna and sardines probably relies on the high content of omega-3 fatty acids, especially if compared with other fish and seafood [75].
Overall, low-fat diets could play an important role in the clinical management of $\mathrm{AK}$, as well as the prevention of SCC.

\section{Antioxidant and Vitamin Intake}

Antioxidants such as vitamin E or $\mathrm{C}$ are known to act as free radical scavengers and they can reduce lipid peroxidation damage. Indeed, nutritional studies have shown how antioxidants of the skin provide protection against the formation of UV-induced cholesterol $\alpha$-oxide [76]. Animal studies have shown less frequent actinic lesions and SCCs when receiving antioxidants [77]. Oral nicotinamide (vitamin $B_{3}$ ) prevents UV radiation-induced immunosuppression which is triggered by DNA damage [78, 79]. The underlying mechanism may rely on its capacity to prevent ATP depletion, thereby boosting cellular energy and enhancing DNA repair [80, 81]. Several doubleblind randomized controlled trials have shown how oral administration of nicotinamide effectively reduces AK count $[82,83]$. A phase II placebo-controlled study with $500 \mathrm{mg}$ of orally administered nicotinamide twice or once daily has shown a $35 \%$ and $29 \%$ relative reduction in $\mathrm{AK}$ count at 4 months respectively. What is more, the study showed lower odds of developing skin cancer when compared with placebo [82]. Later, a phase III randomized trial also demonstrated a lower rate of AK and NMSC among high-risk patients treated with $500 \mathrm{mg}$ of nicotinamide twice daily for 12 months [83]. Clinical studies have also indicated that consumption of green leafy vegetables in individuals with history of skin cancer prevents SCC [66]. Green leafy vegetables contain a variety of vitamins, minerals and other bioactive substances that may protect against cancers, including the antioxidants lutein, vitamins $\mathrm{C}$ and E, flavonoids and folate, which is implicated in DNA synthesis and repair [84]. Nevertheless, the potential beneficial effect of many vitamins such as vitamin $A$, vitamin $E$, vitamin $C$ and carotenoids and selenium has been assessed in many epidemiologic studies and the relationship with SCC has been, at best, weak [85] (Table 2). We did not find any study showing the relationship between nutritional factors and $\mathrm{BD}$. 
Table 2 Epidemiological studies evaluating the association between vitamins, minerals and NMSC

\begin{tabular}{|c|c|c|c|c|}
\hline Reference & Type of study & $\begin{array}{l}\text { No. of } \\
\text { individuals }\end{array}$ & $\begin{array}{l}\text { Vitamins and minerals } \\
\text { analysed }\end{array}$ & Main outcome \\
\hline $\begin{array}{l}\text { Kune et al. } \\
{[86]}\end{array}$ & l study & $\begin{array}{l}88 \text { cases }+88 \\
\text { controls }\end{array}$ & $\begin{array}{l}\beta \text {-Carotene and } \\
\text { vitamin } \mathrm{C} \text { serum } \\
\text { concentration }\end{array}$ & $\begin{array}{l}\beta \text {-Carotene- and vitamin C-containing } \\
\text { foods appear to be protective for both } \\
\text { SCC and BCC. Cases had a lower mean } \\
\text { serum level of } \beta \text {-carotene }(p<0.001) \\
\text { and vitamin A }(p=0.02)\end{array}$ \\
\hline $\begin{array}{c}\text { Karagas } \\
\text { et al. } \\
\text { [87] }\end{array}$ & $\begin{array}{l}\text { Nested case-control } \\
\text { study }\end{array}$ & $\begin{array}{l}132 \\
\text { cases }+264 \\
\text { controls }\end{array}$ & $\begin{array}{l}\text { Selenium, } \alpha \text {-tocopherol, } \\
\beta \text {-carotene and } \\
\text { retinol serum } \\
\text { concentration }\end{array}$ & $\begin{array}{l}\text { No association was found between the } \\
\text { concentrations of any of these nutrients } \\
\text { and SCC }\end{array}$ \\
\hline $\begin{array}{l}\text { Frieling } \\
\text { et al. } \\
\text { [88] }\end{array}$ & $\begin{array}{l}\text { Randomized, } \\
\text { double-blind, } \\
\text { placebo- } \\
\text { controlled trial }\end{array}$ & 22,071 & $\begin{array}{l}12 \text { years of } 50 \mathrm{mg} \text { of } \beta \text { - } \\
\text { carotene } \\
\text { supplementation on } \\
\text { alternate days }\end{array}$ & $\begin{array}{l}\text { An average of } 12 \text { years of supplementation } \\
\text { with } \beta \text {-carotene does not affect the } \\
\text { development of both BCC and SCC }\end{array}$ \\
\hline $\begin{array}{l}\text { Green } \\
\text { et al. } \\
\text { [89] }\end{array}$ & $\begin{array}{l}\text { Community-based } \\
\text { randomized } \\
\text { controlled trial }\end{array}$ & 1621 & $\begin{array}{l}30 \mathrm{mg} \text { of } \beta \text {-carotene } \\
\text { supplementation per } \\
\text { day }\end{array}$ & $\begin{array}{l}\text { No beneficial or harmful effect on the } \\
\text { rates of SCC and BCC as a result of } \beta \text { - } \\
\text { carotene supplementation }\end{array}$ \\
\hline $\begin{array}{l}\text { Greenberg } \\
\text { et al. } \\
{[90]}\end{array}$ & $\begin{array}{l}\text { Randomized clinical } \\
\text { trial }\end{array}$ & 1805 & $\begin{array}{l}50 \mathrm{mg} \text { of } \beta \text {-carotene } \\
\text { supplementation per } \\
\text { day }\end{array}$ & $\begin{array}{l}\text { In persons with a previous nonmelanoma } \\
\text { skin cancer, treatment with } \beta \text {-carotene } \\
\text { does not reduce the occurrence of new } \\
\text { skin cancer over a } 5 \text {-year period }\end{array}$ \\
\hline $\begin{array}{l}\text { Moon } \\
\text { et al. } \\
{[91]}\end{array}$ & $\begin{array}{l}\text { Randomized, } \\
\text { double-blind, } \\
\text { controlled trial }\end{array}$ & 2297 & $\begin{array}{l}25,000 \mathrm{IU} \text { of oral } \\
\text { retinol } \\
\text { supplementation per } \\
\text { day }\end{array}$ & $\begin{array}{l}\text { Daily supplementation with } 25,000 \text { IU of } \\
\text { retinol was effective in preventing SCC, } \\
\text { although it did not prevent BCC }\end{array}$ \\
\hline $\begin{array}{l}\text { Duffield- } \\
\text { Lillico } \\
\text { et al. } \\
\text { [92] }\end{array}$ & $\begin{array}{l}\text { Double-blind, } \\
\text { randomized, } \\
\text { placebo- } \\
\text { controlled clinical } \\
\text { trial }\end{array}$ & 1312 & $\begin{array}{l}200 \mu \mathrm{g} \text { daily selenium } \\
\text { supplementation }\end{array}$ & $\begin{array}{l}\text { Selenium supplementation is ineffective at } \\
\text { preventing BCC and it increases the risk } \\
\text { of SCC and total NMSC }\end{array}$ \\
\hline
\end{tabular}

$B C C$ basal cell carcinoma, NMSC non-melanoma skin cancer, $S C C$ squamous cell carcinoma

\section{Lifestyle Factors}

\section{Alcohol Consumption}

A longitudinal study conducted in Australia in the 1990s, using a validated food-frequency questionnaire, showed that moderate consumption of wine (average of half a glass per day) significantly reduced the rate of acquisition of new AKs [74]. There are several classes of compounds on which polyphenols from wine could exert a biological effect. The most important polyphenols include flavonoids (quercetin, catechin, anthocyanins) and nonflavonoids (resveratrol), which are considered 
powerful antioxidants and are bioavailable after wine consumption [93]. Nevertheless, there is more and more evidence that flavonoids are unlikely to act as major antioxidants but rather through modulation of signalling cascades such as the MAP kinase pathway [94]. Polyphenols, especially resveratrol, have demonstrated antiinflammatory and also anticancer properties, including inhibition of tumorigenesis $[95,96]$, and they also inhibit UVR damage in human skin cells [97]. It should be considered that the concentration of trans-resveratrol varies depending on the quality and type of wine. Specifically, red wines have a concentration of between 0.1 and $14.3 \mathrm{mg} / \mathrm{L}$ while white wines rank much lower $(<0.1-2.1 \mathrm{mg} / \mathrm{L})$ [98, 99]. Proprietary formulations with resveratrol have been developed for skin rejuvenation due to its antioxidant and anti-aging properties [100], but not for AK and SCC. Since resveratrol has been shown to inhibit the growth of human skin SCC A431 xenograft in nude mice by inducing apoptosis and suppressing survivin and the activation of caspase-3 [101], it would be of interest to test the potential beneficial effect of topical resveratrol in the treatment of $\mathrm{AK}$ and SCC. Nonetheless, the anticarcinogenic properties of wine should be considered carefully since acetaldehyde, the first ethanol metabolite, is a cancer-causing agent [102]. In fact, alcohol drinking is positively associated with SCC in a dose-dependent manner [103], and is an independent risk factor of $\mathrm{AK}$ according to a retrospective observational study [104]. Nevertheless, we did not find any study pointing to this association in BD.

\section{Cigarette Smoking}

Epidemiologic studies evaluating the effect of cigarette smoking in $\mathrm{AK}$ are scarce, and although several studies have assessed the possible positive association, statistical significance has never been reached [105, 106]. Nevertheless, it would be advisable for patients with $\mathrm{AK}$ to stop smoking since it has been reported to be associated with SCC in many studies [107-112], including prospective $[107,108]$ and case-control studies [109-112]. Some of them have also reported a dose-response relationship in SCC with number of cigarettes [110-112], years smoked and pack-years of smoking [112].

\section{Environmental Factors}

\section{Viral Infections}

Human papillomaviruses (HPV) are ubiquitous viruses that infect the skin [113] and have been reported to be responsible for cervical carcinoma [114] and oropharyngeal carcinoma [115] among others. Regarding actinic lesions and NMSC, a cross-sectional study of skin swabs demonstrated that HPV species 1 and 2 of the Betapapillomavirus genus were associated with the presence of AK. Indeed, a greater number of HPV types per sample was found in individuals with AK or SCC or AK alone than in healthy participants [116]. Other studies have also demonstrated the relationship between Betapapillomavirus species 2 with SCC, especially in sun-exposed sites [117]. The preferential finding of HPV DNA in sun-exposed sites might be due to increased promoter activity after UV irradiation [118], as well as decreased apoptosis [119]. Specifically, the inhibition of apoptosis in response to UV damage by the E6 protein from a range of cutaneous HPV types may play a key role in providing a survival advantage to genetically damaged keratinocytes, resulting in AK and SCC [120]. Epidermodysplasia verruciformis-associated HPV (EV-HPVs) are possibly involved in the development of $\mathrm{AK}$, as has been demonstrated in serological studies, and may play a role in the pathogenesis of SCC [120, 121]. Interestingly, an observational report with 9-valent HPV vaccination as adjunctive, off-label management of AK showed AK regression beginning within months of the first injection, leading to the clearance of thousands of lesions before the vaccination protocol was completed [122]. Regarding the possible association with other viral infections, the literature is scarce and controversial. While one study suggested the association of human herpesvirus 8 (HHV-8) with proliferative skin lesions [123], another study suggested that both HHV-8 and Epstein-Barr virus do not play an etiological role in cutaneous oncogenesis [124]. $\mathrm{BD}$ has also been associated with HPV infections 
in many epidemiological studies [125-130]. Several serotypes have been associated with BD including HPV-6 and HPV-18 co-infection [126], HPV-58 sub-lineage A1 [125], HPV-31 [130], HPV-11, -16 and -18 [128]. Prevalence of HPV infection in patients with BD varies greatly from $4.8 \%$ [130] to 68\% [129], according to different studies. A retrospective study showed that HPV detection rate was significantly higher in pelvic BD compared to non-pelvic BD [127]. Conversely, one clinical study involving two cases of BD failed to detect evidence of HPV infection [131]. BD has also been associated with Merkel cell polyomavirus infection in a Brazilian population study [132].

\section{Chemical Contaminants}

A strong positive correlation has been established between arsenic and chromium concentration and AK and NMSC [133]. Most human arsenic exposure occurs from consumption of contaminated water. Skin lesions are the first signs of chronic arsenic exposure [134]. Several arsenic poisoning outbreaks have been reported in Bangladesh and India due to the introduction of deep tube-pumps to obtain drinking water from underground sources $[135,136]$. A population study assessing water levels of arsenic and skin lesions in India showed that the age-adjusted prevalence of keratosis was strongly related to water arsenic levels, rising from zero for the lowest exposure level $(<0.05 \mathrm{mg} / \mathrm{L})$ to 10.7 and 8.3 per 100 for male and female individuals, respectively, for the highest exposure level (>0.8 mg/L) [136]. BD has also been associated with arsenic exposure in several case-report publications [137-139]. Water from areas of endemic arsenic poisoning clearly needs to be thoroughly analysed as a preventive measure. Other sources of exposure to chemical contaminants may arise during exposure in certain occupations. Aside from outdoor workers, keratoses and skin cancers can arise in other workers exposed to chemical carcinogens such as coal tar products and arsenic: tar keratoses or arsenical keratoses are a clear example. Tar keratoses may appear years after exposure to coal distillation products (e.g. coal tar, pitch, shale oil) [140]. Arsenical keratoses usually appear on the palms of the hands and soles of the feet after ingestion of arsenic and can progress to SCC [140]. Arsenic $\left(\mathrm{As}^{3+}\right)$ may induce large deletion mutations leading to genomic instability [141], which is a hallmark of cancer, and it is likely to act as a tumour promoter by stimulating Jun kinases (JNKs), AP1 , c-jun and c-fos [142]. Arsenic is used in many industrial processes, including the manufacture of semiconductors, glass and also insecticides and herbicides [140]. It is also produced as a byproduct in the smelting of copper, lead and zinc. Workers may also be exposed to arsenic in its mining and smelting [140]. Farmers are exposed to arsenic pesticides and thereby exposed to increased risk of AK and SCC. There are other pesticides such as paraquat which have also been reported to be potentially carcinogenic [143]. The relationship between paraquat and keratosis, hyperkeratosis and SCC has been controversial. Some studies have reported an increased risk of developing these lesions in paraquat manufacturers, probably due to exposure to tarry by-products in the production process [144, 145]. Conversely, other studies have reported no significant association between paraquat and keratoses or other skin lesions [146-148]. SCC, the malignant progression of $\mathrm{AK}$, may also result from polycyclic aromatic hydrocarbons (PAH), which are the main carcinogens present in tar, pitch, soot and raw paraffin [140]. To understand the risks of industrial processes thoroughly it is crucial to design better prevention strategies such as personal protective equipment (PPE), coupled with educational projects to encourage the early detection of premalignant lesions.

\section{Air Pollution}

Urban air pollution is a complex mixture of gases and particles with condensed organic matter. The major sources of airborne pollutants are mainly from incomplete burning of materials derived from fossil fuels, vegetative sources or mixtures of these materials (e.g. garbage, waste and coal) [149]. As the outermost organ, the skin is exposed to many air pollutants such as $\mathrm{PAH}$, volatile organic compounds, oxides, particulate matter (PM) and ozone which have detrimental effects on the skin [150]. 
Particulate Matter PM consists of complex mixtures of particles suspended in the air which vary in size and composition. It is categorized according to the size of the particles: coarse particles larger than $1 \mu \mathrm{m}$ diameter (e.g. $\mathrm{PM}_{2.5}$ and $\mathrm{PM}_{10}$ ), fine particles smaller than $1 \mu \mathrm{m}$, and ultrafine particles smaller than $0.1 \mu \mathrm{m}$. The major components are metals, organic compounds such as PAH and endotoxins, materials of biologic origin, ions and particle carbon core. They are produced in factories, power plants, refuse incinerators, motor vehicles, construction activity, fires and natural windblown dust [151]. PM penetrates into barrier-disrupted skin through hair follicles or across the stratum corneum, causing inflammation and increased levels of IL-8, matrix metalloproteinase-1 (MMP-1) and reactive oxygen species (ROS), which have detrimental effects in the skin. Indeed, PM leads to neutrophil infiltration in the deep dermis, as well as epidermal thickening. Most PM that penetrates into the skin consists of fine particles that are hazardous for human skin [152]. A semi-individual cohort study showed that an increase in $\mathrm{PM}_{10}$ of $10 \mu \mathrm{g} /$ $\mathrm{m}^{3}$ was associated with a $52 \%$ increase in relative risk of NMSC [153]. Another epidemiologic study demonstrated that urban $\mathrm{PM}_{10}$ air pollution in São Paulo was associated with incidence and mortality of skin cancer [154]. Accordingly, a higher residential green space level should have a protective effect for NMSC in areas with low to moderate UV intensity.

Polycyclic Aromatic Hydrocarbons PAH are the largest class of chemical compounds, ranked ninth most threatening and known to cause cancer. They are present ubiquitously in the environment as pollutants and are formed by the incomplete combustion of almost any fuel such as motor vehicle emissions, residential heating and pollution from industrial machines and are transported through the atmosphere in the vapour phase. Indoor air sources of PAH exposure include tobacco smoke, fumes from open fires, kerosene heaters and cooking. Humans are exposed to PAH by inhalation, ingestion and skin contact, which bioaccumulate in soft tissues, binding to DNA and causing mutations that result in cancer $[149,155,156]$.
The PAH benzo[a]pyrene $(\mathrm{BaP})$ and dibenzo[def,p]chrysene (DBC) both produced SCC in an FVB/N mouse skin tumour model [157]. The carcinogenic effect of PAH is mediated through the interaction with their receptor, the aryl hydrocarbon receptor (AhR), and subsequent activation of CYP1A1. This protein constitutes a member of the cytochrome P450 family, which is responsible for the degradation of $\mathrm{PAH}$, resulting in the formation of highly carcinogenic diol-epoxide metabolites that form DNA adducts. Indeed, $\mathrm{AhR}^{+/+}$mice exposed to airborne PM developed SCCs while $\mathrm{AhR}^{-/-}$did not [158]. Interestingly, animal studies have demonstrated that resveratrol, a natural AhR antagonist, inhibits BaP-induced CYP1A1 expression and subsequent formation of DNA adducts [159]. It has also been demonstrated that UVA combined with BaP significantly increases the risk of skin cancer [160]. In cell culture, BaP synergistically increases the formation of 8-hydroxy-2'-deoxyguanosine (8OHdG) in combination with UVA [161]. BaP serves as a photosensitizer to generate massive ROS upon UVA irradiation which in turn causes oxidative damage and BaP-DNA binding (genetic effect), and potentiates the activation of signal transduction cascades (epigenetic effect), thereby leading to carcinogenesis. In fact, topical application in mice of BaP followed by UVA significantly increased the skin tumour incidence and multiplicity compared with UVA or BaP treatment alone [162]. Photoproducts resulting from UVB radiation are also able to activate AhR, which leads to subsequent activation of cytochrome P450 1A1 and EGF receptor internalization with activation of the EGF receptor downstream target ERK1/2 and subsequent induction of cyclooxygenase- 2 (COX-2), which is involved in SCC development by generating pro-inflammatory and antiapoptotic metabolites [163]. In addition, the UVB-sensitive transcription factor AhR attenuates the clearance of UVB-induced cyclobutene pyrimidine dimers in human $\mathrm{HaCaT} \mathrm{KC}$ and skin from SKH-1 hairless mice by inhibition of p27 tumour suppressor protein [164]. Interestingly, the AhR has been identified as a locus significantly associated with SCC development in a genome-wide association study [165]. 
Regarding BD, we did not find any study evaluating the potential role of air pollution.

Ozone Ozone is an unstable toxic gas normally found in the stratosphere, where it plays a beneficial role in filtering out the short-wave spectrum of UV radiation. Unfortunately, growing emissions of chlorofluorocarbon molecules are causing a diminution in the ozone layer, resulting in more UVB reaching the Earth's surface [166]. Consequently, for every $1 \%$ decrease in ozone there is a $2 \%$ increase in UVB irradiance, and therefore a $2 \%$ increase in skin cancer is predicted [167]. Specifically, each percentage point degradation in the $\mathrm{O}_{3}$ layer thickness would raise the incidence of SCC by $3 \%$ to $4.6 \%$ [168, 169]. Surprisingly, large reductions in UV irradiance have been observed in polluted urban areas when compared to pristine locations. While the cleaner atmosphere in Lauder, New Zealand is undoubtedly beneficial for health, its effect on UV may not be. During the summer, mean UVB irradiances in Tokyo are approximately $40 \%$ less than in Lauder for the same solar zenith angle. These differences are slightly smaller in the winter, and in the UVA region. The effects of pollution in Tokyo impose large reductions in UV irradiances compared with those at the pristine Lauder site. The reductions in UV in Tokyo become progressively larger as the wavelength decreases through the UVA and UVB regions [170]. While ozone in the upper atmosphere (stratosphere) occurs naturally and protects skin by filtering out harmful solar ultraviolet radiation, ozone at ground level (troposphere) is a noxious, highly reactive oxidant pollutant [171]. It is formed in photochemical smog reactions, with the interaction of sunlight (UVR) with hydrocarbons, VOCs, NOx, carbon monoxide (CO) and other pollutants [150]. Acute ozone exposure depletes skin vitamins $\mathrm{C}$ and $\mathrm{E}$ and induces lipid peroxidation in upper epidermal layers. The stratum corneum, as the penetration barrier of the body, appears to be particularly susceptible to ozoneinduced oxidative stress. Such processes at superficial skin layers lead to barrier perturbations and could trigger inflammatory responses in adjacent skin layers [172]. Nevertheless, to the best of our knowledge there is no evidence claiming that tropospheric ozone causes SCC.

\section{CONCLUSIONS}

The main environmental risk factor for the development of AK, BD and SCC is UVR exposure, which has a clear significant effect, in combination with other host factors (e.g. phototype, gender, and light-coloured hair and eyes). Accordingly, photoprotection is clearly advisable, especially for patients with skin cancer and individuals prone to sunburn. Nevertheless, the exposome of AK, BD and SCC should not be restricted to UVR since many other exposome factors play a relevant role in the disease onset and progression. Historically, the exposome of AK, BD and SCC has mainly focused on UVR, and the interactions with other exposome factors are missed or poorly understood. Clearly, the independent effect of these other potential risk factors is difficult to quantify, and inconsistencies and controversial data are due to the confounding effect of sun exposure. However, many exposome factors interact with each other on a genetic background to produce a specific biological response. In addition to photoprotection it would be advisable to take care of the microbiota, by avoiding excessive hygiene, eating omega-3 fatty acids (e.g. salmon), avoiding excessive fatty acid meals, following a regular diet rich in antioxidants, stopping smoking and being aware of the potential occupational risk factors. Undoubtedly, the exposome of $\mathrm{AK}, \mathrm{BD}$ and SCC presented here will help not only to understand AK and SCC etiopathology but also to understand the underlying mechanisms of malignant transformation and be able to design tailored prevention strategies which complement sunscreens and avoidance of sun exposure.

\section{ACKNOWLEDGEMENTS}

Funding. ISDIN provided funding for the journal's rapid service fee and illustrations. No other funding was received for this study. 
Authorship. All named authors meet the International Committee of Medical Journal Editors (ICMJE) criteria for authorship for this article, take responsibility for the integrity of the work as a whole, and have given their approval for this version to be published.

Author Contributions. All authors contributed to the study conception and design. Material preparation, data collection and analysis were performed by all authors. The first draft of the manuscript was written by Manuel Molina-García and all authors commented on previous versions of the manuscript. All authors read and approved the final manuscript.

Disclosures. Susana Puig and Manuel Molina declare that they have nothing to disclose. Corinne Granger, Aurora Garre and Carles Trullàs are employees of ISDIN. Dr. Josep Malvehy has nothing to disclose.

Compliance with Ethics Guidelines. This article is based on previously conducted studies, and does not involve any new studies of human or animal subjects performed by any of the authors.

Data Availability. Data sharing is not applicable to this article as no datasets were generated or analysed during the current study.

Open Access. This article is licensed under a Creative Commons Attribution-NonCommercial 4.0 International License, which permits any non-commercial use, sharing, adaptation, distribution and reproduction in any medium or format, as long as you give appropriate credit to the original author(s) and the source, provide a link to the Creative Commons licence, and indicate if changes were made. The images or other third party material in this article are included in the article's Creative Commons licence, unless indicated otherwise in a credit line to the material. If material is not included in the article's Creative Commons licence and your intended use is not permitted by statutory regulation or exceeds the permitted use, you will need to obtain permission directly from the copyright holder. To view a copy of this licence, visit http://creativecommons.org/licenses/bync/4.0/.

\section{REFERENCES}

1. Marks R, Rennie G, Selwood TS. Malignant transformation of solar keratoses to squamous cell carcinoma. Lancet. 1988;1(8589):795-7.

2. Berker D, McGregor JM, Hughes BR, British Association of Dermatologists Therapy Guidelines and Audit Subcommittee. Guidelines for the management of actinic keratoses. Br J Dermatol. 2007;156: 222-30.

3. Stockfleth E, Kerl H, Guideline Subcommittee of the European Dermatology Forum. Guidelines for the management of actinic keratoses. Eur J Dermatol. 2006;16:599-606.

4. Heaphy MR Jr, Ackerman AB. The nature of solar keratosis: a critical review in historical perspective. J Am Acad Dermatol. 2000;43(1 Pt 1):138-50.

5. De Oliveira ECV, da Motta VRV, Pantoja PC, et al. Actinic keratosis-review for clinical practice. Int J Dermatol. 2019;58(4):400-7.

6. Cockerell CJ. Histopathology of incipient intraepidermal squamous cell carcinoma ("actinic keratosis"). J Am Acad Dermatol. 2000;42(1 Pt 2):11-7.

7. Yantsos VA, Conrad N, Zabawski E, Cockerell CJ. Incipient intraepidermal cutaneous squamous cell carcinoma: a proposal for reclassifying and grading solar (actinic) keratoses. Semin Cutan Med Surg. 1999;18:3-14.

8. Röwert-Huber J, Patel MJ, Forschner T, et al. Actinic keratosis is an early in situ squamous cell carcinoma: a proposal for reclassification. Br J Dermatol. 2007;156(3):8-12.

9. Cassarino D, Dadras S, Matthew R, et al. Diagnostic pathology: neoplastic dermatopathology. 2nd ed. Elsevier; 2017. p. 80-3.

10. Neagu TP, Tiglis M, Botezatu D, et al. Clinical, histological and therapeutic features of Bowen's disease. Rom J Morphol Embryol. 2017;58(1):33-40.

11. Rossi R, Mori M, Lotti T. Actinic keratosis. Int J Dermatol. 2007;47:895-904.

12. Fernández-Figueras MT. From actinic keratosis to squamous cell carcinoma: pathophysiology revisited. J Eur Acad Dermatol Venereol. 2017;31(2):5-7. 
13. Bath-Hextall FJ, Matin RN, Wilkinson D, LeonardiBee J. Interventions for cutaneous Bowen's disease. Cochrane Database Syst Rev. 2013;6:CD007281.

14. Siegel JA, Korgavkar K, Weinstock MA. Current perspective on actinic keratosis: a review. Br J Dermatol. 2017;177(2):350-8.

15. Werner RN, Sammain A, Erdmann R, Hartmann V, Stockfleth E, Nast A. The natural history of actinic keratosis: a systematic review. $\mathrm{Br} J$ Dermatol. 2013;169(3):502-18.

16. Green AC. Epidemiology of actinic keratoses. Curr Probl Dermatol. 2015;46:1-7.

17. Burton KA, Ashack KA, Khachemoune A. Cutaneous squamous cell carcinoma: a review of high-risk and metastatic disease. Am J Clin Dermatol. 2016;17(5): 491-508.

18. Green AC, Olsen CM. Cutaneous squamous cell carcinoma: an epidemiological review. Br J Dermatol. $2017 ; 177(2): 373-81$.

19. Gupta AK, Paquet M, Villanueva E, Brintnell W. Interventions for actinic keratoses. Cochrane Database Syst Rev. 2012;12(12):CD004415.

20. Lomas A, Leonardi-Bee J, Bath-Hextall F. A systematic review of worldwide incidence of nonmelanoma skin cancer. Br J Dermatol. 2012;166: 1069-80.

21. Sandoval M, Ortiz M, Díaz C, Majerson D, Molgó M. Cutaneous manifestations in renal transplant recipients of Santiago, Chile. Transplant Proc. 2009;41(9):3752-4.

22. Keller B, Braathen LR, Hans-Peter M, Hunger RE. Skin cancers in renal transplant recipients: a description of the renal transplant cohort in Bern. Swiss Med Wkly. 2010;140:w13036.

23. Wallingford SC, Russell SA, Vail A, Proby CM, Lear JT, Green AC. Actinic keratoses, actinic field change and associations with squamous cell carcinoma in renal transplant recipients in Manchester, UK. Acta Derm Venereol. 2015;95:830-4.

24. Sahebian A, Pandeya N, Chambers DC, Soyer HP, Green AC. High prevalence of skin cancers and actinic keratoses in lung transplant recipients. J Heart Lung Transplant. 2018;37(3):420-2.

25. Traianou A, Ulrich M, Apalla Z, et al. Risk factors for actinic keratosis in eight European centres: a casecontrol study. Br J Dermatol. 2012;167(2):36-42.

26. De Vries E, Trakatelli M, Kalabalikis D, et al. Known and potential new risk factors for skin cancer in
European populations: a multicentre case-control study. Br J Dermatol. 2012;167(2):1-13.

27. Molho-Pessach V, Lotem M. Ultraviolet radiation and cutaneous carcinogenesis. Curr Probl Dermatol. 2007;35:14-27.

28. Schmitt JV, Miot HA. Actinic keratosis: a clinical and epidemiological revision. An Bras Dermatol. 2012;87(3):425-34.

29. Wild CP. Complementing the genome with an "exposome": the outstanding challenge of environmental exposure measurement in molecular epidemiology. Cancer Epidemiol Biomarkers. 2005;14:1847-50.

30. Miller GW, Jones DP. The nature of nurture. Refining the definition of the exposome. Toxicol Sci. 2014;137(1):1-2. https://doi.org/10.1093/toxsci/ kft251.

31. Dodds A, Chia A, Shumack S. Actinic keratosis. Rationale and management. Dermatol Ther. 2014;4: $11-31$.

32. Byrd AL, Belkaid Y, Segre JA. The human skin microbiome. Nat Rev Microbiol. 2018;16(3):143-55.

33. Kullander J, Forslund O, Dillner J. Staphylococcus aureus and squamous cell carcinoma of the skin. Cancer Epidemiol Biomarkers Prev. 2009;18(2): 472-8.

34. Wood DLA, Lachner N, Tan JM, et al. A natural history of actinic keratosis and cutaneous squamous cell carcinoma microbiomes. MBio. 2018;9(5): e01432-18.

35. Madhusudhan N, Pausan MR, Halwachs B, et al. Molecular profiling of keratinocyte skin tumors links Staphylococcus aureus overabundance and increased human $\beta$-defensin- 2 expression to growth promotion of squamous cell carcinoma. Cancers. 2020;12(3):541.

36. Ohshima $\mathrm{H}$, Bartsch $\mathrm{H}$. Chronic infections and inflammatory processes as cancer risk factors: possible role of nitric oxide in carcinogenesis. Mutat Res. 1994;305(2):253-64.

37. Aggarwal BB, Shishodia S, Sandur SK, Pandey MJ, Sethi G. Inflammation and cancer: how hot is the link? Biochem Pharmacol. 2006;72(11):1605-21.

38. Balkwill F, Mantovani A. Inflammation and cancer: back to Virchow? Lancet. 2001;357:539-45.

39. Chang AH, Parsonnet J. Role of bacteria in oncogenesis. Clin Microbiol Rev. 2010;23(4):837-57. 
40. Andersson T, Bergdahl GE, Saleh K, et al. Common skin bacteria protect their host from oxidative stress through secreted antioxidant RoxP. Sci Rep. 2019;9(1):3596.

41. Dragneva Y, Anuradha CD, Valeva A, Hoffmann A, Bhakdi S, Husmann M. Subcytocidal attack by staphylococcal $\alpha$-toxin activates NF- $\mathrm{BB}$ and induces interleukin-8 production. Infect Immun. 2001;69: 2630-5.

42. Niyonsaba F, Ushio H, Nakano N, et al. Antimicrobial peptides human $\beta$-defensins stimulate epidermal keratinocyte migration, proliferation and production of proinflammatory cytokines and chemokines. J Invest Dermatol. 2007;127(3):594-604.

43. Nakatsuji T, Chen TH, Butcher AM, et al. A commensal strain of Staphylococcus epidermidis protects against skin neoplasia. Sci Adv. 2018;4(2):eaa04502.

44. Souak D, Barreau M, Courtois A, et al. Challenging cosmetic innovation: the skin microbiota and probiotics protect the skin from UV-induced damage. Microorganisms. 2021;9(5):936.

45. Skowron K, Bauza-Kaszewska J, Kraszewska Z, et al. Human skin microbiome: impact of intrinsic and extrinsic factors on skin microbiota. Microorganisms. 2021;9(3):543.

46. Zouboulis CC. The human skin as a hormone target and an endocrine gland. Hormones. 2004;3(1): 9-26.

47. Mahamat-Saleh Y, Aune D, Schlesinger S. 25-Hydroxyvitamin D status, vitamin D intake, and skin cancer risk: a systematic review and dose-response meta-analysis of prospective studies. Nature. 2020;10:13151.

48. Bikle DD. Vitamin D and skin cancer. J Nutr. 2004;134:3472-8.

49. Napgal S, Na S, Rathnachalam R. Noncalcemic actions of vitamin D receptor ligands. Endocr Rev. 2005;26(5):662-87.

50. Slominsky A, Brozyna AA, Zmijewski MA, et al. The role of classical and novel forms of vitamin $D$ in the pathogenesis and progression of nonmelanoma skin cancers. Adv Exp Med Biol. 2020;1268:257-83.

51. Seifert M, Rech M, Meineke V, Tilgen W, Reichrath J. Differential biological effects of 1,25-dihydroxyvitamin $\mathrm{D}_{3}$ on melanoma cell lines in vitro. J Steroid Biochem Mol Biol. 2004;89-90(1-5):375-9.

52. Tang JY, Xiao TZ, Oda $Y$, et al. Vitamin $\mathrm{D}_{3}$ inhibits hedgehog signaling and proliferation in murine basal cell carcinomas. Cancer Prev Res. 2011;4(5): 744-51.
53. Tang JY, Parimi N, Wu A, et al. Inverse association between serum $25(\mathrm{OH})$ vitamin $\mathrm{D}$ levels and nonmelanoma skin cancer in elderly men. Cancer Causes Control. 2010;21(3):387-91.

54. Liang G, Nan H, Qureshi AA, Han J. Pre-diagnostic plasma 25-hydroxyvitamin D levels and risk of nonmelanoma skin cancer in women. PLoS ONE. 2012;7(4):e35211.

55. Eide MJ, Johnson DA, Jacobsen GR, et al. Vitamin D and nonmelanoma skin cancer in a health maintenance organization cohort. Arch Dermatol. 2011;147(12):1379-84.

56. Hosseini MS, Salarvand F, Ehsani AH, et al. Relationship between level of serum 25-hydroxyvitamin D and risk of squamous cell carcinoma in an Iranian population. Dermatol Pract Concept. 2019;9(4):278-82.

57. Van Deventer L, Kannenberg SMH, du Toit J. Vitamin D status in adult patients with nonmelanoma skin cancer in Cape Town, South Africa: a crosssectional study. Int j Dermatol. 2018;57(8):922-7.

58. Sertznig P, Seifert M, Tilgen W, Reichrath J. Peroxisome proliferator-activated receptors (PPARs) and the human skin: importance of PPARs in skin physiology and dermatologic diseases. Am J Clin Dermatol. 2008;9(1):15-31.

59. Baumann CA, Rusch HP. Effect of diet on tumors induced by ultraviolet light. Am J Cancer. 1939;35: 213-21.

60. Black HS, Lenger WA, Gerguis J, Thornby JI. Relation of antioxidants and level of dietary lipid to epidermal lipid peroxidation and ultraviolet carcinogenesis. Cancer Res. 1985;45:6254-9.

61. Black HS. Influence of dietary factors on actinicallyinduced skin cancer. Mutat Res. 1998;422(1): 185-90.

62. Tannenbaum A, Silverstone H. The influence of the degree of caloric restriction on the formation of skin tumors and hepatomas in mice. Cancer Res. 1949;9(12):724-7.

63. Boutwell RK. Diet and anticarcinogenesis in the mouse skin two-stage model. Cancer Res. 1983;43(5):2465s-8s.

64. Birt DF, Pinch HJ, Barnett T, Phan A, Dimitroff K. Inhibition of skin tumor promotion by restriction of fat and carbohydrate calories in SENCAR mice. Cancer Res. 1993;53:27-31.

65. Black HS, Herd A, Goldberg LH, et al. Effect of a lowfat diet on the incidence of actinic keratosis. N Engl J Med. 1994;330(18):1272-5. 
66. Hughes MC, Van der Pols JC, Marks GC, Green AC. Food intake and risk of squamous cell carcinoma of the skin in a community: the Nambour Skin Cancer Cohort Study. Int J Cancer. 2006;119:1953-60.

67. Ibiebele TI, Van der Pols JC, Hughes MC, Marks GC, Williams GM, Green AC. Dietary pattern in association with squamous cell carcinoma of the skin: a prospective study. Am J Clin Nutr. 2007;85:1401-8.

68. Ibiebele TI, van der Pols JC, Hughes MC, Marks GC, Green AC. Dietary fat intake and risk of skin cancer: a prospective study in Australian adults. Int J Cancer. 2009; 125:1678-84.

69. Girotti A. Mechanisms of lipid peroxidation. J Free Radic Biol Med. 1985;1(2):87-95.

70. Lo W, Black H. Formation of cholesterol-derived photoproducts in human skin. J Invest Dermatol. 1972;58(5):278-83.

71. Black HS. Can diet prevent nonmelanoma skin cancer progression? Expert Rev Anticancer Ther. 2005;5(5):801-8.

72. Black HS, Thornby JI, Gerguis J, Lenger W. Influence of dietary omega-6, -3 fatty acid sources on the initiation and promotion stages of photocarcinogenesis. Photochem Photobiol. 1992;56(2):195-9.

73. Black HS, Rhodes LE. The potential of omega-3 fatty acids in the prevention of non-melanoma skin cancer. Cancer Detect Prev. 2006;30(3):224-32.

74. Hughes MCB, Williams GM, Fourtanier A, Green AC. Food intake, dietary patterns, and actinic keratoses of the skin: a longitudinal study. Am J Clin Nutr. 2009;89(4):1246-55.

75. Wall R, Ross RP, Fitzgerald GF, Stanton C. Fatty acids from fish: the anti-inflammatory potential of long-chain omega-3 fatty acids. Nutr Rev. 2010;68(5):280-9.

76. Lo W, Black HS. Inhibition of carcinogen formation in skin irradiated with ultraviolet light. Nature. 1973;246:489-91.

77. Black HS, Chan JT. Suppression of ultraviolet lightinduced tumor formation by dietary antioxidants. J Invest Dermatol. 1975;65(4):412-4.

78. Yiasemides E, Sivapirabu G, Halliday GM, Park J, Damian DL. Oral nicotinamide protects against ultraviolet radiation-induced immunosuppression in humans. Carcinogenesis. 2009;30(1):101-5.

79. Kuchel JM, Barnetson RS, Halliday GM. Cyclobutane pyrimidine dimer formation is a molecular trigger for solar-simulated ultraviolet radiation- induced suppression of memory immunity in humans. Photochem Photobiol Sci. 2005;4:577-82.

80. Park J, Halliday GM, Surjana D, Damian DL. Nicotinamide prevents ultraviolet radiation-induced cellular energy loss. Photochem Photobiol. 2010;86:942-8.

81. Surjana D, Halliday GM, Damian DL. Nicotinamide enhances repair of ultraviolet radiation-induced DNA damage in human keratinocytes and ex-vivo skin. Carcinogenesis. 2013;34:1144-9.

82. Surjana D, Halliday GM, Martin AJ, Moloney FJ, Damian DL. Oral nicotinamide reduces actinic keratoses in phase II double-blinded randomized controlled trials. J Invest Dermatol. 2012;132(5): 1497-500.

83. Chen AC, Martin AJ, Choy B, et al. A phase 3 randomized trial of nicotinamide for skin cancer chemoprevention. N Engl J Med. 2015;373(17): 1618-26.

84. Steinmetz KA, Potter JD. Vegetables, fruit, and cancer prevention: a review. J Am Diet Assoc. 1996;96(10):1027-39.

85. McNaughton SA, Marks GC, Green AC. Role of dietary factors in the development of basal cell cancer and squamous cell cancer of the skin. Cancer Epidemiol Biomarkers Prev. 2005;14(7):1596-607.

86. Kune GA, Bannerman S, Field B, et al. Diet, alcohol, smoking, serum beta-carotene, and vitamin A in male nonmelanocytic skin cancer patients and controls. Nutr Cancer. 1992;18(3):237-44.

87. Karagas MR, Greenberg ER, Nierenberg D, et al. Risk of squamous cell carcinoma of the skin in relation to plasma selenium, alpha-tocopherol, beta-carotene, and retinol: a nested case-control study. Cancer Epidemiol Biomarkers Prev. 1997;6(1):25-9.

88. Frieling UM, Schaumberg DA, Kupper TS, Muntwyler J, Hennekens $\mathrm{CH}$. A randomized, 12-year primary-prevention trial of beta carotene supplementation for nonmelanoma skin cancer in the physician's health study. Arch Dermatol. 2000;136(2):179-84.

89. Green A, Williams G, Neale R, et al. Daily sunscreen application and betacarotene supplementation in prevention of basal-cell and squamous-cell carcinomas of the skin: a randomised controlled trial. Lancet. 1999;354(9180):723-9.

90. Greenberg ER, Baron JA, Stukel TA, et al. A clinical trial of beta carotene to prevent basal-cell and squamous-cell cancers of the skin. The Skin Cancer Prevention Study Group. N Engl J Med. 1990;323(12):789-95. 
91. Moon TE, Levine N, Cartmel B, et al. Effect of retinol in preventing squamous cell skin cancer in moderate-risk subjects: a randomized, double-blind, controlled trial. Southwest Skin Cancer Prevention Study Group. Cancer Epidemiol Biomarkers Prev. 1997;6(11):949-56.

92. Duffield-Lillico AJ, Slate EH, Reid ME, et al. Selenium supplementation and secondary prevention of nonmelanoma skin cancer in a randomized trial. J Natl Cancer Inst. 2003;95(19):1477-81.

93. Haseeb S, Alexander B, Santi RL, Liprandi AS, Baranchuk A. What's in wine? A clinician's perspective. Trends Cardiovasc Med. 2019;29(2):97-106.

94. Williams RJ, Spencer JPE, Rice-Evans CR. Flavonoids: antioxidants or signalling molecules? Free Radic Biol Med. 2004;36(7):838-49.

95. Soleas GJ, Grass L, Josephy PD, Goldberg DM, Diamandis EP. A comparison of the anticarcinogenic properties of four red wine polyphenols. Clin Biochem. 2002;35(2):119-24.

96. Jang M, Cai L, Udeani GO, et al. Cancer chemopreventive activity of resveratrol, a natural product derived from grapes. Science. 1997;275(5297): 218-20.

97. Basu-Modak S, Ali D, Gordon M, et al. Suppression of UVA-mediated release of labile iron by epicatechin-a link to lysosomal protection. Free Radic Biol Med. 2006;41(8):1197-204.

98. Baur JA, Sinclair DA. Therapeutic potential of resveratrol: the in vivo evidence. Nat Rev Drug Discov. 2006;5(6):493-506.

99. Rauf A, Imran M, Butt MS, Nadeem M, Peters DG, Mubarak MS. Resveratrol as an anti-cancer agent: a review. Crit Rev Food Sci Nutr. 2018;58(9):1428-47.

100. Pentek T, Newenhouse E, O'Brien B, Chauhan AS. Development of a topical resveratrol formulation for commercial applications using dendrimer nanotechnology. Molecules. 2017;22(1):137.

101. Hao YQ, Huang WX, Feng HX, et al. Study of apoptosis related factors regulatory mechanism of resveratrol to human skin squamous cell carcinoma A431 xenograft in nude mice. Zhonghua Yi Xue Za Zhi. 2013;93(6):464-8.

102. Seitz HK, Stickel F. Molecular mechanisms of alcohol-mediated carcinogenesis. Nat Rev Cancer. 2007;7(8):599-612.

103. Yen H, Dhana A, Okhovat JP, Qureshi A, Keum N, Cho E. Alcohol intake and risk of nonmelanoma skin cancer: a systematic review and dose-response meta-analysis. Br J Dermatol. 2017;177(3):696-707.
104. Fargnoli MC, Altomare G, Benati E, et al. Prevalence and risk factors of actinic keratosis in patients attending Italian dermatology clinics. Eur J Dermatol. 2017;27(6):599-608.

105. Fania L, Abeni D, Esposito I, et al. Behavioral and demographic factors associated with occurrence of non-melanoma skin cancer in organ transplant recipients. G Ital Dermatol Venereol. 2020;155(5): 669-75.

106. Akdeniz M, Hahnel E, Ulrich C, Blume-Peytavi U, Kottner J. Prevalence and associated factors of skin cancer in aged nursing home residents: a multicenter prevalence study. PLoS ONE. 2019;14(4): e0215379.

107. Karagas MR, Stukel TA, Greenberg R, et al. Risk of subsequent basal cell carcinoma and squamous cell carcinoma of the skin among patients with prior skin cancer. JAMA. 1992;267(24):3305-10.

108. Grodstein F, Speizer FE, Hunter DJ. A prospective study of incident squamous cell carcinoma of the skin in the nurses' health study. J Natl Cancer Inst. 1995;87(14):1061-6.

109. Aubry F, MacGibbon B. Risk factors of squamous cell carcinoma of the skin. A case-control study in the Montreal region. Cancer. 1985;15(4):907-11.

110. De Hertog SA, Wensveen CA, Bastiaens MT, et al. Relation between smoking and skin cancer. J Clin Oncol. 2001;19(1):231-8.

111. López EPM, Miñarro-Del Moral RM, Martínez-García $\mathrm{C}$, et al. Lifestyles, environmental and phenotypic factors associated with lip cancer: a casecontrol study in southern Spain. Br J Cancer. 2003;88(11):1702-7.

112. Rollison DE, Iannacone MR, Messina JL, et al. Casecontrol study of smoking and non-melanoma skin cancer. Cancer Causes Control. 2012;23(2):245-54.

113. Antonsson A, Forslund O, Ekberg H, Sterner G, Hansson BG. The ubiquity and impressive genomic diversity of human skin papillomaviruses suggest a commensalic nature of these viruses. J Virol. 2000;74:11636-41.

114. Pett MR, Alazawi WO, Roberts I, et al. Acquisition of high-level chromosomal instability is associated with integration of human papillomavirus type 16 in cervical keratinocytes. Cancer Res. 2004;64(4): 1359-68.

115. Syrjänen S. The role of human papillomavirus infection in head and neck cancers. Ann Oncol. 2010;21(7):vii 243-5. 
116. Alotaibi L, Provost N, Gagnon S, Franco EL, Coutlée F. Diversity of cutaneous human papillomavirus types in individuals with and without skin lesion. J Clin Virol. 2006;36:133-40.

117. Forslund O, Iftner T, Andersson K, et al. Cutaneous human papillomaviruses found in sun-exposed skin: beta-papillomavirus species 2 predominates in squamous cell carcinoma. J Infect Dis. 2007;196(6): 876-83.

118. Purdie KJ, Pennington J, Proby CM, et al. The promoter of a novel human papillomavirus (HPV77) associated with skin cancer displays UV responsiveness, which is mediated through a consensus p53 binding sequence. EMBO J. 1999;18(19): 5359-69.

119. Jackson S, Storey A. E6 proteins from diverse cutaneous HPV types inhibit apoptosis in response to UV damage. Oncogene. 2000;19(4):592-8.

120. Bavinck JNB, Feltkamp M, Struij L, Schegget JT. Human papillomavirus infection and skin cancer risk in organ transplant recipients. J Investig Dermatol Symp Proc. 2001;6(3):207-11.

121. Bavinck JN, Stark S, Petridis AK, et al. The presence of antibodies against virus-like particles of epidermodysplasia verruciformis-associated human papillomavirus type 8 in patients with actinic keratoses. Br J Dermatol. 2000;142:103-9.

122. Wenande E, Bech-Thomsen N, Haedersdal M. Reduction in actinic keratoses following 9-valent human papilloma virus vaccination. Dermatol Ther. 2020;33(4):13454.

123. Rady PL, Yen A, Rollefson JL, et al. Herpesvirus-like DNA sequences in non-Kaposi's sarcoma skin lesions of transplant patients. Lancet. 1995;345(8961):1339-40.

124. Kholer S, Kamel OW, Chang PP, Smoller BR. Absence of human herpesvirus 8 and Epstein-Barr virus genome sequences in cutaneous epithelial neoplasms arising in immunosuppressed organtransplant patients. J Cutan Pathol. 1997;24(9): 559-63.

125. Kobayashi K, Tanese K, Kubo A, et al. Identification of a human papillomavirus type 58 lineage in multiple Bowen's disease on the fingers: case report and published work review. J Dermatol. 2018;45(10):1195-8.

126. Eftekhari H, Nejad KG, Azimi SZ, Rafiei R, Mesbah A. Bowen's disease associated with two human papilloma virus types. Acta Med Iran. 2017;55(9):594-6.

127. Baek YS, Jeon J, Kim A, Song HJ, Kim C. Human papillomavirus is more frequently detected in the pelvic than non-pelvic area in patients with squamous cell carcinoma in situ (Bowen's disease). Eur J Dermatol. 2020;30(2):111-8.

128. Idriss $\mathrm{MH}$, Misri R, Boer-Auer A. Orthokeratotic Bowen disease: a histopathologic immunohistochemical and molecular study. J Cutan Pathol. 2016;43(1):24-31.

129. Mii S, Amoh Y, Tanabe K, Kitasato H, Sato Y, Katsuoka K. Nestin expression in Bowen's disease and Bowen's carcinoma associated with human papillomavirus. Eur J Dermatol. 2011;21(4):515-9.

130. Hama N, Ohtsuka T, Yamazaki S. Detection of mucosal human papilloma virus DNA in Bowenoid papulosis, Bowen's disease and squamous cell carcinoma of the skin. J Dermatol. 2006;33(5):331-7.

131. Hsu CK, Chen YC, Yang WL, Hsu KF, Chao SC, Lee YY. Bowen's disease with features resembling myrmecia wart. J Dermatol. 2015;42(1):90-3.

132. Bellot TR, Baez CF, Almeida SG, et al. Molecular prevalence of Merkel cell polyomavirus in nonmelanoma skin cancer in a Brazilian population. Clin Exp Dermatol. 2017;42(4):390-4.

133. Schipani G, Delduca E, Todaro G, et al. Arsenic and chromium levels in hair correlate with actinic keratosis/non melanoma skin cancer: results of an observational controlled study. G Ital Dermatol Venereol. 2020. https://doi.org/10.23736/S03920488.20.06600-6.

134. Yoshida T, Yamauchi H, Sun GF. Chronic health effects in people exposed to arsenic via the drinking water: dose-response relationships in review. Toxicol Appl Pharmacol. 2004;198(3):243-52.

135. Smith AH, Lingas EO, Rahman M. Contamination of drinking-water by arsenic in Bangladesh: a public health emergency. Bull World Health Organ. 2000;78(9):1093-103.

136. Mazumder DNG, Haque R, Ghosh N, et al. Arsenic levels in drinking water and the prevalence of skin lesions in West Bengal, India. Int J Epidemiol. 1998;27(5):871-7.

137. Col M, Col C, Soran A, Sayli BS, Ozturk S. Arsenicrelated Bowen's disease, palmar keratosis, and skin cancer. Environ Health Perspect. 1999;107(8): 687-9.

138. Watson K, Creamer D. Arsenic-induced keratoses and Bowen's disease. Clin Exp Dermatol. 2004;29(1):46-8.

139. Yamaoka H, Ikoma N, Kato $M$, et al. Multiple Bowen's disease in a patient with a history of 
possible arsenic exposure: a case report. Tokai J Exp Clin Med. 2011;36(2):53-7.

140. Gawkrodger DJ. Occupational skin cancers. Occup Med (Lond). 2004;54(7):458-63.

141. Hei TK, Liu SX, Waldren C. Mutagenicity of arsenic in mammalian cells: role of reactive oxygen species. Proc Natl Acad Sci. 1998;95:8103-7.

142. Cavigelli M, Li WW, Lin A, Su B, Yoshioka K, Karin M. The tumor promoter arsenite stimulates AP-1 activity by inhibiting a JNK phosphatase. EMBO J. 1996;15(22):6269-79.

143. Spiewak R. Pesticides as a cause of occupational skin diseases in farmers. Ann Agric Environ Med. 2001;8(1):1-5.

144. Bowra GT, Duffield DP, Osborn AJ, Purchase IF. Premalignant and neoplastic skin lesions associated with occupational exposure to "tarry" byproducts during manufacture of 4,4'-bipyridyl. Br J Ind Med. 1982;39(1):76-81.

145. Wang JD, Li WE, Hu FC, Hu KH. Occupational risk and the development of premalignant skin lesions among paraquat manufacturers. $\mathrm{Br} \mathrm{J}$ Ind Med. 1987;44:196-200.

146. Cooper SP, Downs T, Burau K, et al. A survey of actinic keratoses among paraquat production workers and a nonexposed friend reference group. Am J Ind Med. 1994;25(3):335-47.

147. Howard JK. A clinical survey of paraquat formulation workers. Br J Ind Med. 1979;36(3):220-3.

148. Chester G, Woolen BH. Studies of the occupational exposure of Malaysian plantation workers to paraquat. Br J Ind Med. 1981;38:23-33.

149. Fishbein L. Sources, nature and levels of air pollutants. In: Tomatis L, editor. Air pollution and human cancer. ESO monographs (European School of Oncology). Berlin, Heidelberg: Springer; 1990. p. 9-34.

150. Drakaki E, Dessinioti C, Antoniou CV. Air pollution and the skin. Front Environ Sci. 2014;2(11):1-6.

151. Dagouassat M, Lanone S, Boczkowski J. Interaction of matrix metalloproteinases with pulmonary pollutants. Eur Respir J. 2012;39:1021-32.

152. Jin SP, Li Z, Choi EK, et al. Urban particulate matter in air pollution penetrates into the barrier-disrupted skin and produces ROS-dependent cutaneous inflammatory response in vivo. J Dermatol Sci. 2018;S0923-1811(18):30202.
153. Datzmann T, Markevych I, Trautmann F, Heinrich J, Schmitt J, Falko T. Outdoor air pollution, green space, and cancer incidence in Saxony: a semi-individual cohort study. BMC Public Health. 2018;18(715):1-10.

154. Yanagi Y, Assunçao JV, Barrozo LV. The impact of atmospheric particulate matter on cancer incidence and mortality in the city of Sao Paulo. Brazil Cad Saude Publica. 2012;28(9):1737-48.

155. Boffetta P, Jourenkova N, Gustavsson P. Cancer risk from occupational and environmental exposure to polycyclic aromatic hydrocarbons. Cancer Causes Control. 1997;8(3):444-72.

156. Ifegwu OC, Anyakora C. Chapter Six-polycyclic aromatic hydrocarbons: part I. Exposure Adv Clin Chem. 2015;72(277):304.

157. Siddens LK, Larkin A, Krueger SK, et al. Polycyclic aromatic hydrocarbons as skin carcinogens: comparison of benzo[a]pyrene, dibenzo[def,p]chrysene and three environmental mixtures in the $\mathrm{FVB} / \mathrm{N}$ mouse. Toxicol Appl Pharmacol. 2012;264(3): 377-86.

158. Matsumoto Y, Ide F, Kishi R, et al. Aryl hydrocarbon receptor plays a significant role in mediating airborne particulate-induced carcinogenesis in mice. Environ Sci Technol. 2007;41:3775-80.

159. Revel A, Raanani H, Younglai E, et al. Resveratrol, a natural aryl hydrocarbon receptor antagonist, protects lung from DNA damage and apoptosis caused by benzo[a]pyrene. J Appl Toxicol. 2003;23:255-61.

160. Burke KE, Wei H. Synergistic damage by UVA radiation and pollutants. Toxicol Ind Health. $2009 ; 25(4-5): 219-24$.

161. Liu Z, Lu Y, Rosenstein B, Lebwohl M, Wei H. Benzo[a]pyrene enhances the formation of 8-hydroxy-2'-deoxyguanosine by ultraviolet A radiation in calf thymus DNA and human epidermoid carcinoma cells. Biochemistry. 1998;37:10307-12.

162. Wang Y, Saladi R, Wei H. Synergistic carcinogenesis of chemical carcinogens and long wave-length UVA radiation. Trends Photochem \& Photobio. 2003;10: 31-45.

163. Fritsche E, Schäfer C, Calles C, et al. Lightening up the UV response by identification of the arylhydrocarbon receptor as a cytoplasmic target for ultraviolet B radiation. Proc Natl Acad Sci. 2007;104(21):8851-6.

164. Pollet M, Shaik S, Mescher M, et al. The AHR represses nucleotide excision repair and apoptosis and contributes to UV-induced skin carcinogenesis. Cell Death Differ. 2018;25:1823-36. 
165. Chahal HS, Lin Y, Ransohoff KJ, et al. Genome-wide association study identifies novel susceptibility loci for cutaneous squamous cell carcinoma. Nat Commun. 2016;7:12048.

166. Rowland FS. Stratospheric ozone depletion. Philos Trans R Soc Lond B Biol Sci. 2006;361(1469): 769-90.

167. Goldsmith LA. Skin effects of air pollution. Otolaryngol Head Neck Surg. 1996;114:217-9.

168. Abolhasani R, Araghi F, Tabary M, Aryannejad A, Mashinchi B, Robati RM. The impact of air pollution on skin and related disorders: a comprehensive review. Dermatol Ther. 2021;34:e14840.
169. Balato N, Megna M, Ayala F, Balato A, Napolitano M, Patruno C. Effects of climate changes on skin diseases. Expert Rev Anti Infect Ther. 2014;12(2): 171-81.

170. McKenzie RL, Weinreis C, Johnston PV, et al. Effects of urban pollution on UV spectral irradiances. Atmos Chem Phys. 2008;8:5683-97.

171. Fuks KB, Woodby B, Valacchi G. Skin damage by tropospheric ozone. Hautarzt. 2019. https://doi.org/ 10.1007/s00105-018-4319-y.

172. Thiele JJ, Podda M, Packer L. Tropospheric ozone: an emerging environmental stress to skin. Biol Chem. 1997;378:1299-305. 